\title{
Capturing Sandhills at Last Mountain Lake
}

\author{
by Ralph Stueck, Abernethy
}

My interest in cranes has been great ever since I watched as many as fifteen Whooping Cranes doing a mating dance when I was a barefoot schoolboy. I have become very interested in the Sandhill Cranes which rest each fall at the end of last Mountain Lake; I hope to live to see this area become a real refuge for these wonderful birds.

I have told elsewhere of some of my adventures capturing animals and birds for zoos and parks. In this article I would like to tell about the time I had this September "netting" Sandhills for the Assiniboine Zoo in Winnipeg. I left Abernethy with a permit issued by the Chief Ornithologist of the Department of Northern Affairs, a "Cannon" net loaned me by Mr. Fred Bard, 75 gopher traps with the springs weakened so one could stick a finger in them and three dollars' worth of tranquilizer pills. The pills were for the birds-a treatment recommended by Fred Bard and the veterinary!

After setting the traps in the marsh, stubble fields, etc., I awaited results. The birds would not come within fifty feet of the set-up which was carefully camouflaged, but I caught a couple of Mallards the first day. Next day I decided to try a whirl with the "Boom Net." Mr. Bardd had not been able to find the igniter to put the business off; so I had to make my own device which was a "gate" switch with a half-mile length of nylon cord to the blind. After I set the net up in a stu'bble field, I took a drive around the other side. In a short while I heard a heck of a bang! Looking across with glasses, I saw two cars and two men in the field. Apparently the farmer had brought out the wildlife damage adjuster. They had walked into the cord and put off the whole worksand I didn't manage to catch either one of them!

It took me almost two hours, until it was getting dark, to get the net back in position. After straightening out half a mile of cord back to the blind I was trying to join the cord once more to the "gate" switch, right beside the "barrel" or "cannon." Some way or other in the darkness I let go the switch and the little lever dropped of its own accord into contact. With a flash of fire and a deafening roar, off went the works once more. It lifted me off the ground. This time the two outside balls of the "cannon" broke the rope, and the last I saw of them they were headed for Ottawa! The middle ball didn't break from the rupe, or I guess my car which was out front, would have been a mess.

I slept out on the prairie that night listening to the cranes and thinking upon the ups and downs of capturing wildlife. Next morning I motored to Nokomis where Dr. Miller of the University of Saskatchewan, who was trying to capture cranes for banding, suggested that I take part of his equipment, two balls, for my net; we decided to co-operate on a new venture. That afternoon we set the net once more down on the peninsula leading to the lake. We set it thirty feet from the water with the blind seventy-five yards away.

I was left on my own to guard the net, and about 7:00 p.m. the birds started to come in, landing at the edge of the water about sixty feet from the net. As darkness closed in I noticed some birds had come within thirty to fifty feet of the net. I rose on all fours; one old bird close by gave the warning note of danger"cccc---rr---oul." I slowly got down again. However, the old bird and his flock were moving down, toward the net. I rose up several times in the next five minutes and each time in answer to the warning signal from the leader, the flock moved closer and closer to the net. Suddenly a flock of from fifty to a hundred birds came flying down the lake and landed right on beam. Sweating with excitement, I touched off the blast. With a bang the works exploded and away went the net. I grabbed my flashlight and hit for the net on the run. One bird was flying straight at me. I tried to grab him, but fell flat in the mud. When I got to the net, which was in six inches of water, I

(Continued on page 164) 
at Watrous. An old carcass of an Eared Grebe (Podiceps caspicus) and a recent Swamp Sparrow (Melospiza georgiana) were found. Station personnel informed us that in the past they had occasionally noticed dead birds under the tower. Bird watchers ought to be alert to the possibilities of fatalities at this and other towers and structures, especially during the fall and spring migration. Information obtained in this way, in addition to providing distribution records and specimens, may assist in further understanding the basis for these mortalities and thus in finding ways to help reduce this annual loss of songbirds.

\section{LITERATURE CITED}

Beloher, Margaret. 1961. Birds of Regina. Spec. Pub. No. 3, Sask. Nat. Hist. Soc., Regina.

Brewer, R., and J. A. Ellis. 1958. An analysis of migrating birds killed at a television tower in east-central Illinois, September 1955-May 1957. Awk, 75:400-414.

Gcidfrey, W. E. 1950. Birds of the Cypress Hills and Flotten Lake regions, Saskatchewan. Eull. No. 120, Biol. Series No. 40 , National Museum of Canada.

Kemper, C. A. 1958. Destruction at the TV tower. Passenger Pigeon, 20:3-9.

Kemper, C. A. 1959. More TV tower destruction. Passenger Pigeon, 21:135-142.

Lahrman, F. W. 1959. TV tower casualty list. Blue Jiay, 17:142-143.

Peterson, R. T. 1961. A field guide to western birds. Houghton Mifflin Co., Boston.

\section{AMERICAN GOLDEN PLOVER IN FALL MIGRATION AT HORSESHOE LAKE}

On September 17, 1961, I observed a flock of 17 American Golden Plover at Horseshoe Lake northwest of Yorkton. They were studied in detail while at rest and flushed twice to note flight markings. At rest they appeared generally brown above, three individuals having a distinct golden tinge to their upper parts. In flight, the lack of conspicuous markings was evident-there were no wing bars, rump and tail were evenly dark, and there were no black axillars as in the Black-bellied Plover.

Checking Stuart Houston's list of "The birds of the Yorkton district" (1949. Can. Field-Nat. 63: 215-241) and recent issues of the Blue Jay, $I$ could find no record of this species in fall migration. However,
Audubon Field Notes lists numerous observations for interior regions within the last few years, the nearest being in South Dakota in the autumn of 1958 and 1960 . In the general summary of the 1958 autumn migration reference is made to the continually increasing number of observations which indicate that more individuals are deserting their traditional ocean migration routes in favour of partial or complete overland flights.-William Anaka, Spirit Lake.

EDITOR'S NOTE: It is always difficult to assess how much migration patterns are actually changing, since a lack of good observers and good records may partly explain the apparent absence of a species. It is interesting to noie, as a llatter of comparison, that the American Golden Plover was once considered unknown in the Regina area in fall migration, although Margaret Belcher's Birds of Regina (1961) cites fall records for as early as 1913 . We know of several observations of the Golden Plover again : this fall in the Regina area-a group of 21 was seen October 8 by Frank Brazier and R. W. Nero, and a group of five, with one Black-bellied Plover, on October 21 by $M$. Belcher and L. Murray.

\section{(Continued from page 156)}

he is willing to pay. Planning for lure crop planting must go ahead. If Crown land is not available in sufficient quantity to meet the need, suitable private land adjoining the present sanctuary must be acquired. The farming operations required to produce the lure crop could be carried out by local farmers after bids have been submitted on various contracts. These are sume of the obstacles that will have to be overcome to alleviate the local crop depredation problem. Perhaps some solution to the problem may be forthcoming through the Agricultural Rehabilitation and Development Act.
(Continued from page 157)

counted ten birds but one got out in the next few minutes. Another got tangled in the net and drowned. I got mired in the mud trying to untangle one bird and fell over with a Sandhill Crane in my arms, saying "I love you, Honey, and some day you will be in a beautiful zoo, admired by thousands of children."

I got six Sandhills for the zoo and Dr. Miller banded the two remaining birds. This adventure was almost as exciting as the time I lassoed a live buffalo in Brandon Park and transferred it to Moose Jaw Wild Animal Park for Mr. Paynter, Director of Wildlife. 